\title{
PHOTOGRAMMETRY-DERIVED DIGITAL SURFACE MODEL AND ORTHOIMAGERY OF VALDEZ GLACIER ICE-DAMMED LAKE, VALDEZ, ALASKA, OCTOBER 15, 2014
}

Katreen Wikstrom Jones, Gabriel J. Wolken, Erin N. Whorton, and Michael D. Hendricks

Raw Data File 2019-2

This report has not been reviewed for technical content or for conformity to the editorial standards of dggs.

2019

State of Alaska

Department of Natural Resources

Division of Geological \& Geophysical Surveys 


\section{STATE OF ALASKA}

Michael J. Dunleavy, Governor

DEPARTMENT OF NATURAL RESOURCES

Corri A. Feige, Commissioner

DIVISION OF GEOLOGICAL \& GEOPHYSICAL SURVEYS

Steve Masterman, State Geologist \& Director

Publications produced by the Division of Geological \& Geophysical Surveys are available to download from the DGGS website (dggs.alaska.gov). Publications on hard-copy or digital media can be examined or purchased in the Fairbanks office:

Alaska Division of Geological \& Geophysical Surveys (DGGS) 3354 College Road | Fairbanks, Alaska 99709-3707

Phone: 907.451 .5010 | Fax 907.451.5050

dggspubs@alaska.gov $\mid$ dggs.alaska.gov

DGGS publications are also available at:

Alaska State Library, Historical Collections \& Talking Book Center

395 Whittier Street

Juneau, Alaska 99801

Alaska Resource Library and

Information Services (ARLIS)

3150 C Street, Suite 100

Anchorage, Alaska 99503

\section{Suggested citation:}

Wikstrom Jones, Katreen, Wolken, G.J., Whorton, E.N., and Hendricks, M.D., 2019, Photogrammetry-derived digital surface model and orthoimagery of Valdez Glacier ice-dammed lake, Valdez, Alaska, October 15, 2014: Alaska Division of Geological \& Geophysical Surveys Raw Data File 2019-2, 4 p. http://doi.org/10.14509/30181
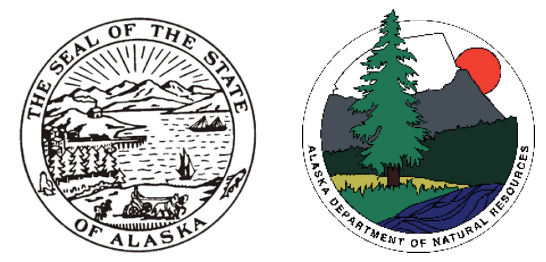


\title{
PHOTOGRAMMETRY-DERIVED DIGITAL SURFACE MODEL AND ORTHOIMAGERY OF VALDEZ GLACIER ICE-DAMMED LAKE, VALDEZ, ALASKA, OCTOBER 15, 2014
}

Katreen Wikstrom Jones, ${ }^{1}$ Gabriel J. Wolken, ${ }^{1}$ Erin N. Whorton, ${ }^{2}$ and Michael D. Hendricks ${ }^{1}$

\begin{abstract}
The State of Alaska Division of Geological \& Geophysical Surveys (DGGS) produced a digital surface model (DSM) and an orthorectified aerial image (orthoimagery, fig. 1) over an ice-dammed lake formed by Valdez Glacier (fig. 2). Aerial photographs and Global Navigation Satellite System (GNSS) data were collected on October 15, 2014, and were processed using Structure-from-Motion (SfM) photogrammetric techniques to create a DSM and orthoimagery. For the purpose of enabling open access to geospatial datasets in Alaska, this collection is being released as a Raw Data File with an open end-user license. All files can be downloaded free of charge from the DGGS website (http://doi.org/10.14509/30181).
\end{abstract}

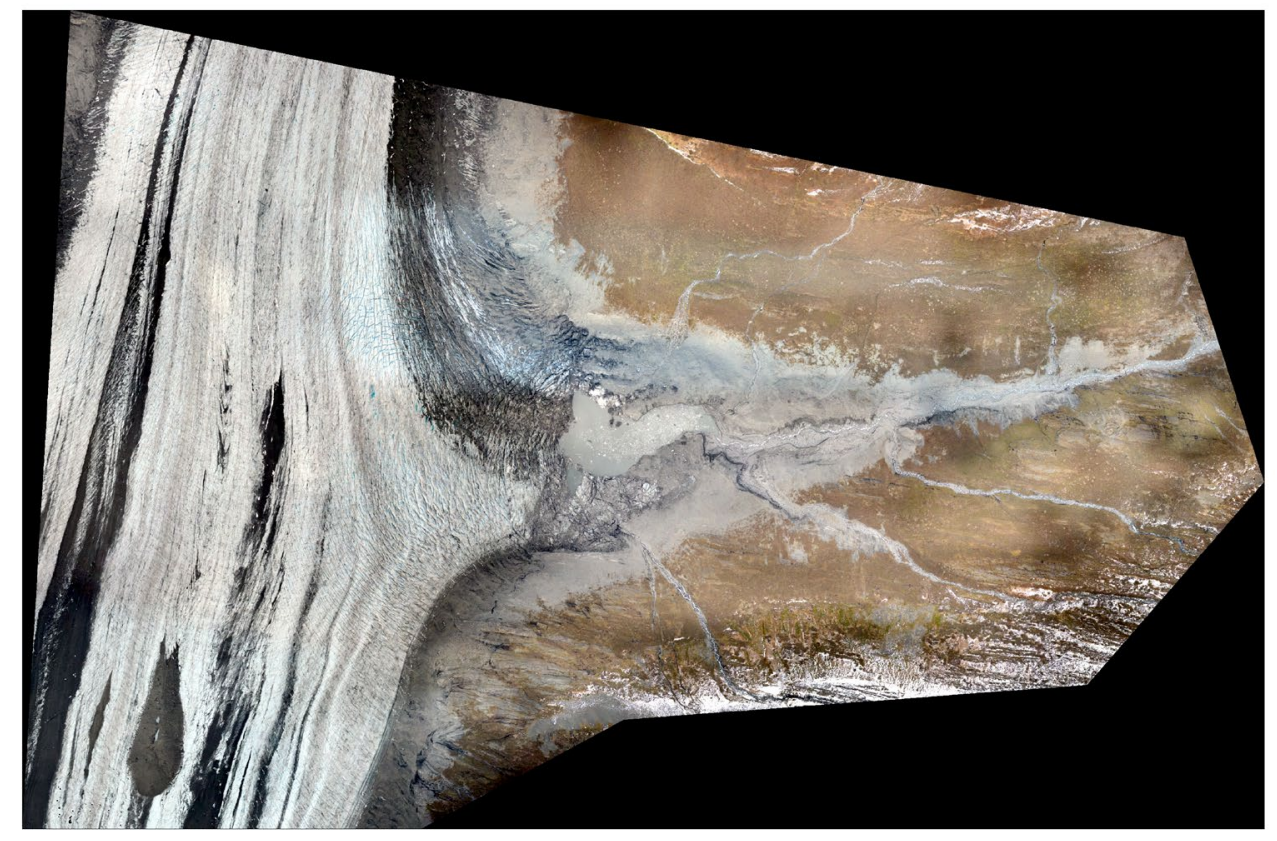

Figure 1. Orthoimagery of Valdez Glacier ice-dammed lake acquired on 10/15/2014.

\footnotetext{
${ }^{1}$ Alaska Division of Geological \& Geophysical Surveys, 3354 College Road, Fairbanks, AK, 99709-3707

${ }^{2}$ Alaska Division of Geological \& Geophysical Surveys, 3354 College Road, Fairbanks, AK, 99709-3707; now at U.S. Geological Survey, 934 Broadway Suite 300, Tacoma, WA 98402
} 


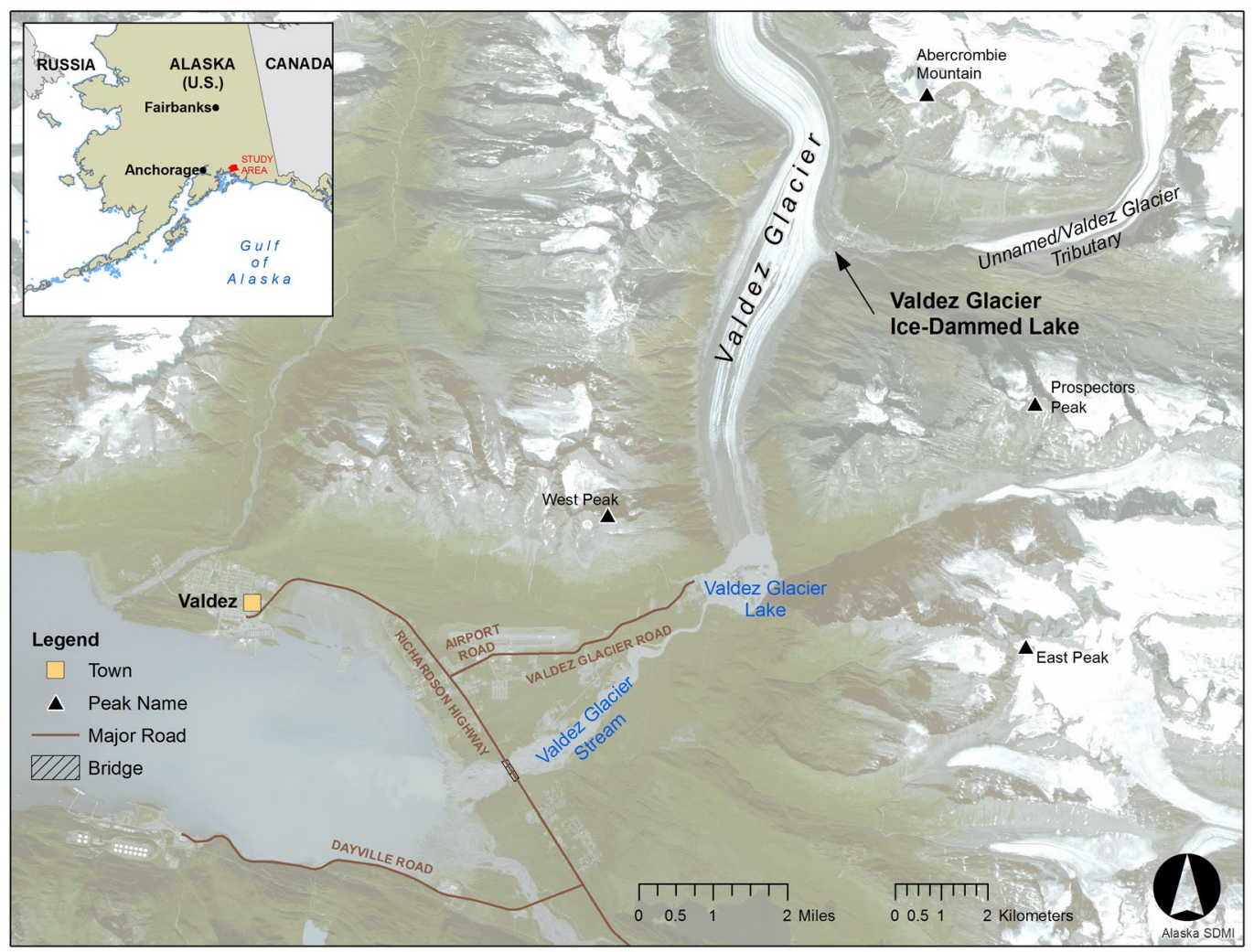

Figure 2. Location of the ice-dammed lake formed by Valdez Glacier (black arrow), indicating the area covered by the orthoimagery and DSM.

\section{DATA ACQUISITION}

The State of Alaska Division of Geological \& Geophysical Surveys collected digital aerial photographic data on October 15, 2014, using a rotary-wing (Robinson 44) airborne platform. The aerial photographic survey resulted in approximately $60 \%$ side lap and $80 \%$ end lap coverage, with an above ground-level flying height of $1100-2000 \mathrm{~m}$, which resulted in 818 photos with $0.096 \mathrm{~m}$ per pixel ground resolution. The total area surveyed was approximately $11 \mathrm{~km}^{2}$.

A Nikon D800 with an AF-Nikkor 28mm f/5D lens was used to collect 36.2-megapixel JPEG photographs (7360 x 4912 pixels per image) which were compressed for optimal quality. The aerial photographic survey was controlled with a custom intervalometer that linked the camera shutter release with Global Positioning System (GPS) event markers. GPS event markers were created by an onboard Topcon Net G3 receiver and a dual-band Topcon PG-A1 antenna mounted approximately $0.02 \mathrm{~m}$ above the camera, with a background sampling frequency of $5 \mathrm{~Hz}$. A GPS base station with a Topcon Hyper-II receiver sampling at $1 \mathrm{~Hz}$ was placed approximately $10 \mathrm{~km}$ from the survey area and was used to differentially correct the aerial survey GPS data using post-processing kinematic (PPK) methods.

Ground control points were not collected at the time of acquisition. 


\section{DATA PROCESSING}

\section{GNSS}

Aerial survey GNSS data (camera coordinates and trajectory data) were processed by DGGS using kinematic (PPK) methods in Topcon Positioning Systems, Inc. Magnet Office Tools commercial GNSS software. Nearby CORS stations were used as the vertical and horizontal control. GNSS data were collected and processed in WGS84 (G1674) using WGS84 ellipsoid. The base station position was corrected using the NGS Online Positioning User Service (OPUS) with the IGS08 (EPOCH 2015.6162). Camera coordinates were converted to the North American Datum 1983 (NAD83; 2011) European Petroleum Survey Group Well Known Identification Number (EPSG) 6335 and the North American Vertical Datum of 1988 (NAVD88; Geoid12A; EPOCH 2010.00) using the National Geodetic Survey (NGS) VDatum tool (version 3.3). The coordinates are projected in UTM Zone 6 North and are in meters.

The converted camera coordinates were manually correlated to image filenames to create a camera exterior orientation file for import into the photogrammetric software, Agisoft Photoscan Professional. The exterior orientation file provides the X, Y, and Z position for each photograph taken during the survey. Yaw, pitch, and roll information were not recorded during the flight.

\section{Photogrammetry}

Aerial stereo-photographs were imported into the commercially available Agisoft Photoscan Professional software (Version 1.2.3 build 2331). Photos were processed in Photoscan on a Windows PC to align aerial photos, edit the sparse point cloud, optimize the bundle block adjustment, construct the dense point cloud and triangulated irregular network geometry, and export the natural color (RGB) orthoimagery GeoTIFF.

\section{DATA PRODUCTS}

Data files available for download are tiled DSM and natural color (RGB) orthoimagery GeoTIFFs. All data are projected in UTM Zone 6 North (meters) using the NAD83 (2011; EPSG 6335) horizontal datum and NAVD88 (Geoid12A; EPOCH 2010.00) vertical datum.

\section{Digital surface model (DSM)}

DSMs represent surface elevations of all surfaces, including vegetation, vegetation-free land, bridges, buildings, etc. The DSM is a single-band, 32-bit float GeoTIFF file, with a ground sample distance (GSD) of $0.19 \mathrm{~m}$. No Data value is set to -32767 .

\section{Orthoimagery}

The orthoimagery is a four-band, 8-bit unsigned GeoTIFF file. The orthoimagery has a GSD of $0.096 \mathrm{~m}$ per pixel, and the "No Data" value is set to 256. 


\section{DATA QUALITY}

The average camera location error was $0.12 \mathrm{~m}$ in the $\mathrm{X}$ direction ( $0.12 \mathrm{~m}$ in the $\mathrm{Y}$ direction), 0.14 $\mathrm{m}$ in the Z, combined XY error of $0.17 \mathrm{~m}$. and resulting total error of $0.22 \mathrm{~m}$. No ground control points, check points, or other reference datasets were available to assess the horizontal and vertical accuracy of the resulting digital surface model and orthoimagery.

The DSM and orthoimagery have been visually inspected for data errors such as pits, border artifacts, and shifting. The end-user should be aware that pits and peaks are present in areas of some small water bodies, such as lakes and ponds, and that DSM data have not been hydro-flattened in these areas.

\section{ACKNOWLEDGMENTS}

These data products were funded by City of Valdez and Alaska Department of Natural Resources, Division of Geological \& Geophysical Surveys. We thank Alpine Air for their aviation expertise and contribution to these data products. 